\title{
The challenges in making library services accessible to incarcerated male juveniles in five correctional schools ${ }^{1}$
}

\author{
E.R.K. Rafedzi ${ }^{1}$, A. Abrizah, A. $^{2}$ and Halida Yu \\ ${ }^{1}$ Faculty of Information Management \\ Universiti Teknologi MARA, Shah Alam, Selangor, MALAYSIA \\ ${ }^{2}$ Department of Library \& Information Science, \\ Faculty of Computer Science \& Information Technology, \\ University of Malaya, Kuala Lumpur, MALAYSIA \\ e-mail: *ezza644@ salam.uitm.edu.my (corresponding author); \\ abrizah@um.edu.my; halid917@salam.uitm.edu.my
}

\begin{abstract}
This qualitative study extends our earlier research on what we have learned about the information needs of Malaysian male juvenile offenders. This study explores the extent to which the prison library is used as the environment for information seeking of male juvenile delinquents. Data were collected using participants' observation with 27 juveniles (13 to 21 years old) living in five correctional schools in Malaysia. Our observation at all research sites has led us to conclude that the prison library does not play much role in addressing the participants' information needs. The findings in this research are useful for the purpose of designing and delivering the best possible library services to this group. findings add to the limited literature on juvenile offenders' information needs and how the prison libraries meet the needs of this people.
\end{abstract}

Keyword: Male juvenile delinquents; Prison library; Youths at risk; Information needs; Information behaviour.

\section{INTRODUCTION}

The importance of education is emphasized on young prisoners (aged 21 years and below) in order to prevent them from relapsing into criminal activities. In the context of Malaysia, young prisoners are exposed to the same educational opportunities that any child would expect in life. They gain formal education and are permitted to sit for public examinations under a special programme by the Ministry of Education, in collaboration with the Malaysian Prisons Department, as the institute of detention and rehabilitation. Teachers are sent to prison to teach the young prisoners for the following academic programs:

a) $3 \mathrm{M}$ remedial classes (basic literacy classes for reading, writing and arithmetic).

b) Pre-PMR classes (lower secondary, 13-14 years old)

c) PMR classes (Lower Certificate of Education, 15 years old)

d) Pre-SPM classes (upper secondary, 15-16 years old)

\footnotetext{
${ }^{1}$ This is a revised version of the paper presented at the Fifth International Conference of Libraries, Information and Society 2014 (ICOLIS 2014), Library: Our Story, Our Time, Our Future, Kuala Lumpur, Malaysia, 4-5 November 2014, under the title "The library for the incarcerated male juveniles: An observation of five correctional schools"
} 
e) SPM classes (equivalent to GCE O level)

f) STPM classes (equivalent to GCE A Level)

g) Diploma / degree classes (for long distance education programs).

The importance of education as a component of rehabilitation have led to the establishment of libraries in prisons, with the view of libraries as important players within the intellectual freedom and social justice agenda (Šimunić, Tanacković, and Badurina 2016). The existence of the academic classes indirectly encourages young prisoners to use the prison library to obtain information related to their education. According to Conrad (2012), the prison library should (a) address the inmate's requirements for information on institutional policies; (b) enable inmates to maintain contact with the outside world, enhance vocational skills; (c) provide educational materials; (d) provide support rehabilitation; (e) provide reading materials for personal recreation; and (f) provide information on re-entering the community after parole. The importance of having prison library in Malaysia is stated in the Prisons Act 1995 : Prisons Regulations 2000 : "a library shall be provided in every prison and, subject to these regulations and to such conditions as the Director General may determine, every prisoner shall be allowed to have library books and to exchange them as often as practicable" (p. 48).

In their analysis of penal architecture, Armstrong and McAra (2006) call for research on "spaces of the prison that have either been neglected in earlier periods of study or which have only become visible under current conditions." (p.23). The prison library is one of those neglected and understudied spaces within the prison. Most librarians still believe in the ideal of rehabilitation and emphasize the library's role in providing materials and programs for this purpose. Although prison libraries in general have come a long way since "the early collections of primarily religious books to which there was limited access", they are still struggling with the mission of "providing the disadvantaged and marginalized members of the society with access to the quality materials to meet the diverse information needs and reading interests" (Šimunić, Tanacković, and Badurina 2016). The information needs of marginalized youth communities such as juvenile delinquents and youths-at-risk in Malaysia and how the library addresses their information needs is still understudied. This is an issue of growing importance that deserves closer investigation in light of rising Internet use amongst youths worldwide, coupled with the prevailing issue of delinquency and risk-taking among youths (Haynie 2002). It is most important that the informational needs of inmates be met as they need information for religious and the prison yard will afford them the opportunity to know and worship God better than before, to improve their education and also to seek for legal redress (Tarzaan, Chorun and Mbatsoron 2015).

Recognizing the lack of attention given by library and information science scholars in Malaysia to libraries in prisons and correctional schools, we aim to fill the gap with this study by finding out how the prison library is used by male juvenile delinquents for education and the challenges they face in fulfilling their information needs. This focus is important to consider when designing and delivering the best possible library and information services to this group. The current study extends our earlier findings on what we have learned so far about the information needs of Malaysian male juvenile offenders (Rafedzi and Abrizah 2016). 


\section{LITERATURE REVIEW}

Past studies (Stevens and Usherwood 1995; Liggett 1996; Lemon 1997; Dixen and Thorson 2001; Curry 2003; Lehmann 2003; Kennedy 2006; Omagbemi and Odunewu 2008; Šimunić, Tanacković, and Badurina 2016) have shown the importance of establishing prison library services to rehabilitate and provide education to inmates. The deprivation of information services to prisoners can be detrimental to the rehabilitation objectives of the prison (Omagbemi and Odunewu 2008). A steady number of studies continued to discuss the different aspects of roles played by prison libraries in rehabilitating the inmates. Lemon (1997) examined the roles of these libraries in providing the necessary resources to meet the informational, cultural and recreational needs of the prison community, while others, (Bayley, Greenfield and Nogueira 1981; Cheeseman 1994; Rubin and Suvak 1995; Collins and Boden 1997; Lemon 1997; McClaskey 1977; Pendleton and Chatman 1998; Wilhelmus 1998; Knudsen 2000; Bowden 2003; Shirley 2003; Stearns 2004; Gilman 2008) specifically focused on the use of prison libraries. In reviewing this literature, it becomes apparent that most of these studies were only focusing on meeting the information needs of adult prisoners.

The benefits of a prison library for its inhabitants have been well-discussed in many studies. Juvenile delinquents are found to benefit the most from using prison library. Cheeseman (1977), described the incarcerated young people's library experience as "journey out of the facility to distant lands, to happier times with imaginary friends and entirely new personalities", p. 126). Cheeseman's opinion on the library usage is echoed in the Guidelines for Library Service to Prisoners (Lehmann and Locke 2005) which states that the prison library is a substitute for the library at home and consequently it reaches nearly every prisoner and that is why it should be developed into one of the best libraries. According to Zeman (2014), in her debut memoir of a prison librarian on the state of juvenile incarceration in the United States, juvenile delinquents have absolute need to read but there was a lack of reading materials in the prison for them. Eze (2014) in highlighting the nature of the prison environment, found out that prisoners who undergo stress, anxiety, fear, insecurity, boredom and lacked direction, would get relief from emotional and psychological instability by using the prison library.

Other studies discuss the need for library education for more meaningful library use. Researchers (Rubin and Suvak 1995; Gilman 2008) emphasized that it is important for each prison to teach the inmates, especially the juvenile delinquents, how to use the library. They need to know the call numbers, book spines, the differences between fiction and nonfiction and the general layout of library resources and facilities. These basic library skills can help them feel comfortable in using the library and the instructions about the library ethos. These can help them feel more comfortable when they are back in the community at large. Library education should also go beyond library skills class. It must be viewed as teaching life skills to the inmates. This is because these skills are not only relevant in the prison library but also serves as a re-entry purpose by presenting any library as a familiar place which former inmates can use on the outside after release.

On the same token, Gilman's (2008) study found that the library is important for juvenile delinquents to gain skills that will help them find employment on the outside. It is more important that they gain skills that will enable them to be socially competent when they return to their communities. Gilman who conducted a survey at Juvenile Detention Centre (JDC) in Washington, Oregon, and Idaho found that 89 percent of respondents believed the most important functions of a library in a detention center were providing recreational 
reading to pass time, and developing literacy skills. The survey also indicated that juveniles used the library services effectively with 50 percent of them using readers' advisory, and another 44 percent forming book discussion groups. The study reported that juveniles have access to a wide range of educational, skill-building treatment and intervention resources that are appropriate and responsive to their interests and needs, as well as those of the community.

Challenges in prison library provision are also documented in several studies, (Koons 1988; Lemon 1997; McClaskey 1977). Lemon (1997) added that the prison library has become a hub for inmates, to assist them with legal issues, education, computer skills, career information, resumes and treatment. He added that the library should provide supplementary materials for inmates' learning and for on-the-job training courses offered at the institution (such as air-conditioning and refrigeration, electrical and construction trades). The collection in the library must also be frequently updated proportionately to the size of the population to serve a wider age range than the average school library. In addition, it does not have the resources of a public library with children, young adult and adult collections to draw on (Cheeseman 1977).

Research on information needs of young inmates in correctional facilities have been few and scarce. Lim et al. (2013) found that emerging digital behaviours via computermediated communication over the Internet are changing the way young inmates seek information. In the emerging digital behaviors' via computer-mediated communication over the Internet, inmates have the same information needs as person in regular society. However, with a greater number of them having low education skills, they experience difficulties to articulate their information needs, or to seek information (Glennor 2006). Prison library service must be designed to meet the informational, cultural, educational, vocational and recreational needs of its users. Libraries should ensure that their roles are compatible with the facility's mission (Shirley 2003). The collections in prison libraries play an important role in supporting the curriculum of prison education, hobbies, or pleasure reading to help pass the large amounts of unstructured time in a positive way. As such, Dixen (2001) emphasized that the prison libraries' collections should have some nonfiction and educational materials for general learning and character improvement.

\section{OBJECTIVE AND METHOD}

The objective of this study is to explore how the prison library is used to support the information needs of the male juvenile delinquents in Malaysian correctional schools. Specifically, the study focuses on the following research questions:

(a) How do male juvenile delinquents use the prison library to support their information needs for education?

(b) What are the barriers to access the information needed by juvenile delinquents?

For the purpose of this research, an information need is considered as the desire or necessity to acquire the materials required by a juvenile delinquent, to ease, resolve, or otherwise address a situation arising in his daily life in prison. Such materials might include facts, interpretations, advice, opinions, or other types of resources carrying information such as books, newspapers and magazines.

Our research took the form of a qualitative research design to establish what information was available for male juveniles in prison and what more could be made available. 
Qualitative research is primarily concerned with meaning, interpretations and giving research participants 'a right of voice' (French and Swain 2004). There is a commitment to see 'through the eyes' of research participants, and a belief that social behavior cannot be grasped until the researchers have understood the symbolic world of the research participants. According to Bailey (2007), qualitative field research requires flexibility, because it can be chaotic, emotional, dangerous and lacking in rigid rules to guide some aspects of the research process. Luck, ambiguity, time constraints and feelings often affect the planning, execution and analysis of field research, making it all the more important for the researchers to be well prepared and trained in this methodology before engaging in it.

The first researcher is committed to get close to the sample being observed in its natural setting and look at the library environment, sources and services prepared for young prisoners which will help them in their rehabilitation and education process. This method is useful to support our earlier interview findings ((Rafedzi and Abrizah 2016); by observing and finding out the needs and interests of the existing sources and services in their prison libraries. According to Grimshaw (2001), the field researcher should observe what is going on in the field, logging the minute detail of every aspect of tribal life; daily routines, the preparing of foods, details of the care of the body, conversations and social life. Forsythe (1998) explained that by asking people to describe their information behavior is less trustworthy than direct observation, because (a) self-report (like eyewitness testimony in court) is often neither accurate nor complete; (b) respondents may believe that their answers reflect their level of professional competence; and (c) investigators may not understand the context of respondents' answers.

This study involved an observation of twenty seven(27) participants from a population of 2,010 (until 20th April 2013) male juvenile delinquents from five correctional schools under the jurisdiction of Malaysian Prison Department. Each school was taken from a different region; the northern, central, eastern and southern parts of West Malaysia). Male juvenile delinquents were chosen because juvenile delinquents in Malaysia were predominantly male (with a male - female ratio of $30: 1$ ) (Jabatan Penjara Malaysia 2013). The male juveniles who met at least one of the following criteria were purposively sampled. The number in parentheses indicated the number of participants who gave their consent to be interviewed and observed for each category specified:

a) Those who have outstanding academic achievements based on PMR, SPM and STPM examination results (5)

b) Those who are still studying at the diploma or degree level (6)

c) Those who are not academically inclined, but are very interested in technical skills / vocational skills (8)

d) Male juvenile delinquent in $3 \mathrm{M}$ classes (4)

e) The youngest male juvenile delinquents (4) (10 to 12 years old)

To avoid identification, all participants are referred to by code numbers. Table 1 summarizes the profiles of the participants observed for each school and the observation sessions held at each prison school library. There was no detailed information about the participants observed reported in this paper; except for the information about their ethnic origin. The observation was done in covert situation, where the researcher's status is not made known to the participants. In terms of ethnic groups, twenty two (22) participants were of Malay origin, one (1) was Chinese and four (4) were Indians.

To explore how the male juvenile delinquents get support from the prison information environment, the researcher was given a place in the library to observe the participants. 
The researcher's observation usually started at 9.00 am and finished at $13.00 \mathrm{pm}$ on schooldays. Sometimes, it finished much earlier due to the prison school activities or due to the lack of prison staff to monitor field observation session. The participants in general were aware that they were involved in a study on prison libraries. However, at the point of observations, they were under the impression that the first researcher came to the library to do her reading or studying (covert situation). As such, they comprehended that the researcher was merely studying and they were free to behave normally as they used to do in the library (non-intrusive observation). The field observation finding was limited to the behaviour of participants in the library. Most of the time, the researcher was just sitting in the library, watching the participants' behavior (spectator). A field log book was used to write the observation notes.

Table 1: Participants Observation Based on the School Location

\begin{tabular}{c||c||l||c||c}
\hline \hline No & $\begin{array}{c}\text { Location } \\
\text { Code }\end{array}$ & $\begin{array}{c}\text { Location of correctional } \\
\text { school }\end{array}$ & $\begin{array}{c}\text { No of participants } \\
\text { (Participant code) }\end{array}$ & Date of Observation Sessions \\
\hline \hline 1 & CO & $\begin{array}{l}\text { Selangor } \\
\text { (Central Observation) }\end{array}$ & $\begin{array}{c}5 \\
\text { (CO1 to CO5) }\end{array}$ & 02 January - 04 June 2013 \\
\hline \hline 2 & EO & $\begin{array}{l}\text { Terengganu } \\
\text { (Eastern Observation) }\end{array}$ & $\begin{array}{c}4 \\
\text { (EO1 to EO4) }\end{array}$ & 14 February - 16 February 2012 \\
\hline \hline 3 & NO & $\begin{array}{l}\text { Kedah } \\
\text { (Northern Observation) }\end{array}$ & $\begin{array}{c}5 \\
\text { (NO1 to NO5) }\end{array}$ & $\begin{array}{l}\text { 09 April - 02 May 2012 } \\
\text { 22 April - 30 May 2013 }\end{array}$ \\
\hline \hline 4 & SO & $\begin{array}{l}\text { Johor } \\
\text { (Southern Observation) }\end{array}$ & $\begin{array}{c}3 \\
\text { (SO1 to SO3) }\end{array}$ & 01 December - 31 January 2013 \\
\hline \hline 5 & CSO & $\begin{array}{l}\text { Melaka } \\
\text { (Central Southern }\end{array}$ & $\begin{array}{c}10 \\
\text { (CSO1 to CSO10) }\end{array}$ & $\begin{array}{l}\text { 05 September - 17 September } \\
\text { 2012 } \\
\text { 09 January - 06 February 2013 }\end{array}$ \\
\hline \hline
\end{tabular}

The participants unknowingly believed that the first researcher was another teacher who wanted to know about how is it like teaching in a correctional school. They addressed her as "Ustazah" (female teacher, commonly refer to a teacher who spread the teachings of Islam), most probably because she conveyed herself as a religious teacher. A commonly acceptable habit or practice of the Malaysian people - they have their pre-conceived idea, perception or judgement of strangers merely by looking at their appearances. For example, someone with skinny jeans, singlet or metal/rock T-shirt and long hair would be regarded as a "mat rock" (rocker) and addressed as "Bro" or "Brader (Brother)". It is very similar to the situation when Malaysians view one's appearance of wearing hijab (a veil covering the head and chest worn in public by Muslim women); it is most likely that the person would be acknowledged as an "Ustazah". Those perceptions will associate someone with simplified greetings such as "Bro", "Brader", "Ustazah" and "Ustaz", when they want to greet or strike a conversation with you. By understanding the practice, the researcher accepts the acknowledgement, and it was not her intention to mislead the participants into believing that she was just another teacher.

Most of the time, the researcher was accompanied by a prison staff and other times, she used to sit alone. The prison staff presence was to ensure the safety of the researcher in the library. In many instances, the prison staff sat outside the library to observe the activities inside the library. There was no change in the furniture position of the library to ensure that the participants were uninformed or unaware of the research (as it always is in unobtrusive observation sessions). This is to ensure that the participants be their normal 
selves for the observation. Before the participants were allowed to enter the library, the researcher took her place first. The researcher also brought with her some current magazines on hobbies, technology and comics. The reason of having those reading materials and put them nearby the researcher was to see whether the participants took the materials to read or not. The selection of magazine for this observation session was decided based on our earlier findings (Rafedzi and Abrizah 2016). During the interview session, most of the research participants were asked for magazines for them to read. They agreed that comics and magazines were the best reading materials for them to read, but the materials were not available at the prison institutions; and they admitted that both reading materials were not allowed in the prison environment. They explained that reading comics and magazines made them happy and could relieve their stress as they enjoyed colorful drawings and funny words. Besides entertainment, those magazines also provided good guidance and motivation which are important for the juvenile delinquents' rehabilitation. From this, it was assumed that it was possible to recognize whether the prison information environment supports the male juvenile information needs and process by lessening their barriers to access the information.

\section{RESULTS AND DISCUSSIONS}

\section{Research question 1: How do male juvenile delinquents use the prison library to support their information needs for education?}

The researchers observed a few patterns of how the prison library support the juvenile delinquents' information needs for education.

a) The library spaces are used mainly by juvenile delinquents taking national-based examination, with the presence of their teacher.

Our first observation was that the prison library is mainly used by juvenile delinquents who are currently enrolled in examination-based classes (PMR, SPM and STPM). Their subject teacher accompanied them to the library for a specific learning purpose, for example, giving instructions on what to read or which book or reference works to refer to. We noticed that when in doubt, or whenever they want to get further information, the participants would approach their teacher, instead of searching for the information from other library resources. These findings are demonstrated in the following observation notes.

\section{(EO, 14 February 2012, 9.00am to 10.00am)}

Four (4) participants enter the library accompanied by their English language teacher. The teacher gives them clear directions of the reason why they go to the library. "Boys, find an English reference textbook to read, or you can answer the PMR sample exam questions". The participants nodded as symbol of understanding their teacher's instruction. After releasing them to find the book, the teacher sits at a reading desk and does her work. The participants then choose their books and sit together at another table. Each has a book in his hand. The library condition is very warm and humid most probably because the school is located close to the beach. The four participants quietly read, and appear to be disciplined and diligent while they are in the library. Once in a while, I (first researcher) hear them trying to pronounce difficult words. EO3 suddenly gets up from his chair and approaches the teacher for help. He asks his teacher how to pronounce the English words as well as their meanings in the Malay language. 
The scenario was almost the same with other research locations. The participants neeed to be accompanied by their teachers to do some classroom tasks in the library or else they would not do their work.

b) Male juvenile delinquents refer to available resource person in the library to address their information needs

Another observation illustrates that the male juvenile delinquents have their own mission when entering the library, even without the presence of a class teacher. Despite the absence of their teacher in the library, they are still being monitored by a prison staff. There are participants who desire to read religious books as advised by their religious education teacher. However, when they require further information or in need of an advice, they would again refer to a resource person, whoever is available in the library.

\section{(CO, 23 January 2013, 9.15am to 9.53am)}

I realize that $\mathrm{CO} 5$ has been staring at me ever since he was at the library entrance. Once he enters the library, he directly approaches and stands in front me. He smiles and greets "Assalamualaikum, ustazah." After that, $\mathrm{CO} 5$ goes to the bookshelves. Three participants are talking about religious matters; and one of them is holding a religious book. After a few minutes, $\mathrm{CO} 5$ approaches me again. The prison officer asks him to stay back and instructs $\mathrm{CO} 5$ to leave the room in his loud and strong voice. CO5 explains to the prison officer that he would like to ask my opinion on a religious matter. The prison officer looks at me and I nod as an okay signal to help CO5. Once I offer CO5 a seat, he slowly pulls a chair and carefully sits down. He shows me a book on Nabi Musa (Moses) and wants to know if it can be used for a write up on the history of prophets. I tell him that it is suffice and that he could also write about the Firaun (Pharaohs) and the glimpse of challenges Moses faced. He thanks me saying.. "Ok. Ok. Thank you, ustazah, Assalamualaikum" and leaves smiling.

The Integrity School teachers admitted that most male juvenile delinquents would like to discuss their homework with their teacher or the library teacher. Sometimes, they would refer to the prison staff if they desperately needed answers to their school homework. However, they would prefer to ask, or to look for answers from new sources rather than their own teacher. This is demonstrated in the following excerpt by one of the teachers at CO: "They love to talk with somebody new at the prison... the 'fresh' face. They always looked for that.. the 'fresh face'. For them, it will be a great day if they can talked with someone new at the library. I mean.. at this place, prison."

c) Male juvenile delinquents enjoy reading light reading materials such as magazines and comics

Our interview findings in Rafedzi and Abrizah (2016) reveal that the majority of the participants acknowledged that reading was not a hobby or interest during their life in the outside world. However, while in prison, most of them indicate that they are more likely to spend time reading novels, short stories, magazines, religious and academic books. Juvenile delinquents who attend diploma or degree classes address their information needs during classroom instructions and when using the Internet. They do not use the library facilities as a result of the lack of suitable reading materials for them. The $3 \mathrm{M}$ students choose to use pre-school books to enhance their reading proficiency, but they show the tendency to like comics and magazines as their reading sources. Most of the magazines are published by the Prison Department of Malaysia. According to a research by Shirley (2003), the prison population mostly uses homegrown newspapers and magazines. 
(NO, 23 April 2013, 10.45 am to $11.27 \mathrm{am})$

NO4 from the $3 M$ class seems interested in the magazines that I bring along with me. He browses towards me, walks to and fro, and touches the magazines laid on my table. He seems to look doubtful and looks around the library. NO4 then moves away and goes straight to the bookshelf next to him, joining in a chat with his friends. He then approached his teacher who is two tables away from me and said something to her. After a while, NO4 comes back towards where I sit, looks at me and asked loudly; "Ustazah, are these yours? Can I read?" I was surprised with the question but quickly smiles to NO4, and then nod as an agreement. NO4 smiles at me, takes one magazine and joins his friends behind the bookshelf. I noticed NO4's happy face when he holds the magazines. I suspect he asks for his teacher's permission to borrow it from me. Sometimes, I hear laughter from behind the bookshelf, as if he and his friends really enjoy the material.

Most of the participants we observed have materials, such as, magazines and comics in their hands when they were in the library. Although they did not get the chance to read the latest and popular magazines in the market, they gave us the impression that they were pleased with the remaining magazines in the library. It appeared to us that they were surprised but interested in the magazines that we brought in the library. We discovered from the teacher that current and popular magazines as well as comics were prohibited in the library. That was perhaps the reason why the participants looked cautious and sought permission as they did not want to be in trouble if caught with forbidden materials.

\section{(CO3, 23 January 2013, 9.15am to 9.53am)}

CO3 looks at me and then lays his eyes on the magazines close to me. He comes towards me, and whispers, "Can [I] see?" I nod and smile simultaneously. $\mathrm{CO} 3$ chooses one magazines, but then he quickly put it back. He stands still for a few seconds, and then lifts another magazine, flips through one page after another and then he puts it back. He looks around and then turns to me and asks if he can bring the magazine over to his friends, while pointing to front direction. I said, 'Take it'. He quickly picks up the magazine and heads towards his friend, CO4. There are two of them. Then all three walks towards the back of the library and stand behind the last row of bookshelves. I cannot see them but I believe they are still under the observation of the prison officer. Another participant, $\mathrm{CO} 5$ who stands not far from me and is holding a religious book, places the book on a table and join the two boys. At 9.50 am, all three come towards me and $\mathrm{CO} 3$ carefully shove the magazine back on my table and thank me before leaving the library. They all seem happy and I hear them laugh quietly.

The prison rules forbid provision of light magazines such as cartoons / comic magazines as a reading source for male juvenile delinquents. In 2015, there are too many cartoons / comic magazines in the market. These types of magazines will help the male juvenile delinquents in the rehabilitation process. It helps them to read. Things that they won't do when they were outside the prison before. It should be noted that, in Malaysia; there are cartoons / comic magazine that based on religion and motivation that can be used by the prison institution for helping the juvenile delinquents. It should also be noted that, there are juvenile delinquents who are illiterate. With the existence of the light reading materials, it will help to build their interest and their attention to read, educate them and delight them. This situation can easily seen by the researcher when when the participants looked very happy when they can freely read the 'prohibition' reading materials. More important, to the some extent; they feel free and it can reduce their pressure while in 
prison. The importance of these materials in assisting the juvenile delinquents' rehabilitation process is demonstrated in the following excerpt: There is not much colour in our room. We can see.. I don't know what is the colour of my room! It seems like, I will be one of those colour blind people. But, this comic, this magazine, this book at the library helped me a lot to see colour. I can see blue, red, green." (E2, 11 January 2012; Rape case).

Even for the $3 \mathrm{M}$ classes, who cannot read well; found enjoyment in reading comics because they can understand the pictures to know the whole story: "I see only pictures. I don't know how to read. I only see pictures and I assumed to know the whole story." (S2, 28 July 2013; Drug possession). This shows that inmates love magazines since they do not require as much effort or time to read as books, provide images which help transport their minds out of the confines of prison and even create built-in positive social situations as they pass the magazines along to friends.

\section{Research question 2: What are the barriers to access the information needed by juvenile delinquents?}

Our observation at all research sites led us to conclude that there were some barriers, limiting the juvenile delinquents from enjoying full access to the information they needed. The following findings demonstrates the need for a well-thought-out library sources and services, especially if the prison library is committed to serving the educational, recreational and rehabilitation information needs of these young prisoners.

\section{a) The prison library houses books on religion but has limited, irrelevant and outdated resources}

Shirley (2003) listed several collections of items that should not be allowed in a prison library, such as true crime stories with inmate's photographs, bombs, disguises, selfdefense materials, and pornography. As expected, none of the libraries we observed had materials of this genre. All prison libraries we observed housed collections of references books and textbooks for national examination, and teenage and family novels. All libraries had many reference works on religion such as the Al-Quran, its translation, stories of the prophets, biographies and memoirs of national personalities, and self-motivational magazine and pamphlets. According to Sullivan (2008), religious readings help to reform the character of inmates and contributed to a number of redemptions. Prisoners admitted to have a dire need for information that could give them emotional and spiritual stability to be in good terms with God and men and become better citizens in the society (Eze 2014). However, there are noticeably limited titles of children's story books, dictionaries and encyclopedias. Based on the web portal Books to Prisoners (www.bookstoprisoners.net), the highly requested books from prisoners in 2014 are dictionaries, thesauruses, any books on starting or running business, and trade books.

Our inspection of the bookshelves confirmed that many books were outdated, especially the collections of references books and textbooks for national examination, which were obsolete for the current syllabus. There were practically no academic books suitable for those pursuing their bachelor and diploma degree, as well as books for technical or vocational classes. Ajogwu (2006) found that enumerated prisoners' information needs range from legal needs, religious, health, educational, vocational and recreational to financial needs. Therefore, prison library could develop collections that include a broad range of materials for self-help, self-education, community resources, housing, job availability, and vocational training opportunities. These types of information will encourage the inmates to make full use of the prison library. 
The researchers had the opportunity to see several boxes of books received by the prison library as gifts and donations to the prison. All the boxes contained reading materials contributed either by private or government agencies. The prison management usually did not preclude any types of reading materials contributed by these agencies. Typically, the materials were sorted out before they were placed in the library. We found these materials were mostly outdated, irrelevant, and the contents were not useful for the current information needs of the juvenile delinquents. Some of these materials include the examination books for PMR, SPM, and STPM that were no longer used in the present school syllabus and a set of encyclopedia published in 1980's. There were even nine copies of the 1992 Annual Report of a company in the library. The teachers we met indicated that they were aware of the presence of the books, however they said that they did not comment or act upon it, because the prison authority had consented to accept the donations of the materials.

\section{b) The prison library does not provide a resource person}

Our earlier observation notes, as well as the one below, clearly show the absence of a resource person for the inmates to refer to when they are in the library. The resource person can be a library media specialist who plan and team-teach with subject teachers to integrate reading and information skills programs into the classroom curriculum. Literature indicated that it is possible for library media specialists to realize their potential as resource persons who co-plan and implement instruction in collaboration with teachers (McGiffin 1990). A peer support group is extremely valuable for self-directed educational growth and rehabilitation development among the young inmates and the presence of a resource person may facilitate this process. The findings for this study are presented in the following observation notes.

\section{(SO, 28 January $2013,11.00 \mathrm{am}$ to $12.04 \mathrm{pm}$ )}

A female Malay language teacher directs her three students into the library. She instructs them to find any information on general issues in Malaysia; from any newspapers, magazine and books. She tells them that all the information would be used for quizzes and short essays. The boys listen without asking any questions, and after about three minutes, they move to the bookshelves and look for the relevant materials. Initially, their attention is only on the books that are available on the bookshelves. They browse the shelves and when each has a book in hand, they sit at the nearest table and begin to flip the book page by page. After a while, they seem not interested with the materials and they appear to be restless. All three of them stop looking at the books. SO3 stands up and goes to the teacher who is standing at the library counter. He says something to her, perhaps telling her that he is not able to get anything relevant to the topic. The teacher goes to the bookshelves, checks around and tells $\mathrm{SO} 3$ something. SO3 nod his head and he quickly goes to SO1 and SO2. The teacher goes back to the counter. After a while, they go to a big wooden cabinet at the corner of the library. They open the cabinet and release some old newspapers and bring them to the table. They start looking for information and appear to be concentrating on their task, and at times the following utterances are heard: "Can this be?" "Can I choose this?" and sometimes it seems like they are discussing with each other.

\section{c) Prison staff intervention in the information seeking process inhibited or curtailed library usage}

The prison authority comprises personnel such as the prison officers, prison staffs, and warden. It is common for juvenile delinquents to be scared of prison officials as most of them have strict and fierce look, which works well while intimidating inmates. However, 
there are others who are easy going and more friendly. Based on earlier our observation notes, as well as the one below, the young inmates appeared uncomfortable with the presence of the prison staff in the library. Encouragement from prison staffs is very important for the male juvenile delinquents to comfortably use the library collection.

\section{(CO, 23 January $2013,9.15 \mathrm{am}$ to $9.53 \mathrm{am})$}

After choosing the reading materials, the 3 boys take a sit on the clean concrete floor in the aisle between the bookshelves. They sit close to each other. [Researcher's notes: I am not sure why they act in such a way, the library is not that cold as the air conditioner has just been turned on]. I notice that the boys habitually look at the prison officer rather than having their eyes on their books. There are also other inmates who are not interested in choosing books, but had to find one to be read.

\section{CONCLUSION}

The study aimed to contribute to the general awareness of library service providers for incarcerated populations, specifically the juveniles, by exploring how the prison library is used by male juvenile delinquents for education and the challenges they face in fulfilling their information needs. In the paper, it was viewed that prison libraries can be important players within the intellectual freedom and social justice agenda, and help address the information needs of inmates to improve their education. However, the prevalence of unmet information needs in the prison library was apparent in this study. Just like any young people in the free world, the juvenile delinquents need a variety of information for their personal needs as well as for education. The findings reveal that the young people behind the bars in this study are being deprived of basic library services to support both their personal and education needs. The prison libraries are found to be lacking of good collection, where most of the materials provided are mainly books on religion, but have limited, irrelevant and outdated resources. As such, these collections are not positively contributing towards the young people's rehabilitation and learning process. Likewise, these libraries also do not have trained librarians who could be useful resource person to support the juvenile's personal and education needs. It is time for the authority to look seriously into the matter and remodel the juvenile prison library services to effectively support the rehabilitation and learning process of the inmates.

Lehman (2000) wrote that incarcerated persons generally have the same reading interests and information needs as individuals in the free world. All of the research participants agreed that comics and magazine were the best reading materials for them to read, but the materials were not available at the prison institutions. The reason why they choose comics as popular reading materials is because comics will make them happier and relieve stress with colorful drawings and funny words. In Malaysia, comics are the best reading materials for teenagers and children. Comics have their multi subjects for them to choose, such as Majalah Ana Muslim, Majalah Sayang Muslim, Majalah Fokus, Dewan Pelajar, Dewan Siswa, Kawan, and Bintang Kecil. The other magazines that need to be considered by the Malaysian Prison Department are Dewan Budaya, Dewan Masyarakat, Pemikir, Minda, SUKSES, and Dewan Ekonomi. Those magazines are full with guidance and motivation for juvenile delinquents entertainment and also for their rehabilitation. All of the participants also had expressed a strong desire to read magazines and newspapers. Though the current information from newspapers is important for them, but they realize that they could only read the current information from newspapers one month after. Newspapers as a source of information would serve further the purpose of keeping 
residents in touch with the "outside world", thus reducing institutionalization and facilitating their reintegration into the society.

Information needs of juvenile delinquents are more likely related to their (a) academic needs and interests and (b) filling their time while in prison. Apparently, it may be tempting to assume that information seeking failure must be due, in large measure, to shortcomings on the part of the prison libraries themselves. However, the findings of the study indicate that this condition is by no means always the reason. Clearly, it is not due to the young inmates' lack of desire to seek for information but rather, they made inappropriate choices of sources. This is undermined by an ignorance of the prison authority of the information seeking options to the inmates, and of the approaches most likely to be effective when finding information. There were instances of what may be termed as "source and user dislocation" (Pickard 2004) where adult intervention disrupted the youth's efforts to seek for information.

The finding in this study is important in that it provides evidence of how the prison library is used, and could be useful at the beginning of designing information services for juvenile delinquents. This study has two main implications to prison libraries:

(a) In terms of information resources and materials, a special guideline should be adopted for developing the collection of prison library. This is to prevent the dumping of irrelevant and outdated materials in the prison library and to promote appropriate reading materials as needed for different subject matters.

(b) In terms of teaching information skills, the findings highlight the importance of programmes that develop a more collaborative atmosphere between teachers and/or prison officers with the young inmates. Opportunities must be given to inmates to engage interactively with teachers and prison officers in the former's information seeking process.

Malcolm X, who frequently used the library during his imprisonment at Norfolk remarked, 'A book can change a man'; (Malcom X and Haley 1987). This famous quote illustrates the importance of books in prison. The prison library is part of treatment facilities and should provide supplemental materials for inmates, whether for their rehabilitation, education or training processes (Lemon 1997). It is most important that the informational needs of inmates be met. If one believes in library service, one must believe that everyone should have access to it, including inmates. There should be a special conviction that the young prisoners of correctional schools be provided with the best possible information sources and services. As aptly put by Burt (1977), "those on the "inside" now will be on the "outside" soon" (p. 36), signifying that very means of assuring that the juvenile delinquents return to the society as good citizens should be utilized.

\section{ACKNOWLEDGEMENT}

We would like to thank the Malaysian Prison Department for giving us the permission into the five correctional schools, and to the juvenile offenders and teachers who had been very receptive of us. This research received no specific grant from any funding agency in the public, commercial, or not-for-profit sectors. 


\section{REFERENCES}

Armstrong, S. and McAra, L. 2006. Audiences, borders, architecture: The contours of control. In Perspectives on Punishment: The Contours of Control, S. Armstrong and L. McAra (eds.) pp. 1-30. New York: Oxford University Press.

Ajogwu, M. N. 2006. The role of NGOs in providing library and information services to two disadvantaged groups in Nigeria. Global Review of Library and Information Science, Vol. 2: 78-89.

Bailey, C.A. 2007. A guide to qualitative field research. 2nd. ed. California : Thousand Oaks.

Bayley, L., Greenfield, L. and Nogueira, F. 1981. Jail library services : A guide for librarians and jail administrators. Chicago : American Library Association.

Burt, L.N. 1977. Information needs of inmates. In Pool, J. (ed.) Library Services to Correctional Facilities. Library Trends, Vol. 26, no. 1: 27-38.

Bowden, T. S. 2003. A snapshot of state prison libraries with a focus on technology. Behavioral and Social Sciences Librarian, Vol. 21, no. 2: 1.

Cheeseman, M. 1977. Library services to young people and children in correctional facilities. Library Trends, Vol. 26, no. 1: 125-138.

Collins, R and Boden, L. 1997. Guidelines for prison libraries. 2nd ed. USA: Library Association Prison, Libraries Group.

Conrad, S. 2012. Collection development and circulation policies in prison libraries: An exploratory survey of librarians in US correctional institutions. The Library Quarterly, Vol. 82, no. 4: 407.

Curry, A. 2003. Canadian federal prison libraries: A national survey. Journal of Librarianship and Information Science, Vol. 35, no. 3: 1.

Dixen, R. and Thorson, S. 2001. How librarians serve people in prison. Computers in Libraries, Vol. 21, no. 9: 48.

Eze, J. U. 2014. Information needs of prisoners in Southeast Nigerian prisons. Information Development, Vol. 32 no. 3: 243-253. doi:10.1177/0266666914538042.

Forsythe, D. E. 1998. Using ethnography to investigate life scientists' information needs. Bulletin of Medical Library Association, Vol. 86, no. 3: 402.

French, S. and Swain, J. 2004. Researching together : A participatory approach. In Physiotherapy: A psychosocial approach, French S. and Sim J. (eds.) 3rd ed. Oxford: Butterworth-Heinemann.

Gilman, I. 2008. Beyond books: Restorative librarianship in juvenile detention centers. Public Libraries, Vol. 47, no. 1.

Glennor, S. V. 2006. Library services to disadvantaged user groups : Library services to adult prisoners in the United States. LIBREAS. Library Ideas, 6. Available at: http://libreas.eu/ausgabe6/003shir.htm.

Grimshaw, A. 2001. The ethnographers eye: Ways of seeing in modern anthropology. Cambridge: Cambridge University Press.

Haynie, D. L. 2002. Friendship networks and delinquency: The relative nature of peer delinquency. Journal of Quantitative Criminology, Vol. 18, no. 2: 99.

Jabatan Penjara Malaysia. 2013. Jumlah juvana sabitan dan reman yang ditempatkan di setiap penjara di Malaysia sehingga 20 April 2013 (berumur 21 tahun ke bawah). Unpublished report. Kajang : Jabatan Penjara Malaysia.

Jeffries, S. R. 1975. In case of fire, throw this book in! Catholic Library World, Vol. 46: 434.

Kennedy, T. 2006. Libraries without librarians are just a room full of books : A study of NSW corrective services. Australian and Library Information Association. 11p. Available at: http://conferences.alia.org.au/alia2006/Papers/ Toni_Kennedy.pdf

Knudsen, M. 2000. How my library affects my life in prison. Education Libraries, Vol. 24, no. 1: 20 . 
Koons, P. 1988. Lest we forget : Prison libraries. Library Journal, Vol. 15: 51.

Lehmann, V. 2003. Planning and implementing prison libraries: Strategies and resources. Paper presented at $69^{\text {th }}$ IFLA Council and General Conference, 1-9 August 2003, Berlin, Germany.

Lehmann, V. and Locke, J. 2005. Guidelines for library services to prisoners (3d Edition). The Hague: IFLA Headquarters. (IFLA Professional Reports: 92), Revised version of IFLA Professional Report 46.

Lemon, M. 1997. Prison libraries change lives. Information Outlook. Available at: http://findarticles.com/p/articles/mi_m0FWE/is_n11_v1/ai_20078332/pg_2/?tag=co ntent

LeDonne, M. 1977. Survey of library and informational problems in correctional facilities : A retrospective review. Library Trends, Vol. 26, no. 1: 53-70.

Liggett, J.M. 1996. Survey of Ohio's prison libraries. Journal of Interlibrary Loan, Document Delivery and Information Supply, Vol. 7, no. 1: 31

Lim, S.S., Chan, Y.H., Vadrevu, S. and Basnyat, I. 2013. Managing peer relationships online Investigating the use of Facebook by juvenile delinquents and youths-at-risk. Computers in Human Behavior, Vol. 29, no. 8.

Malaysia. Ministry of Internal Affairs. 2000. Prisons act 1995 : Prison regulations 2000 (amendment 2003). Available at: http://www.prison.gov.my/portal/page/portal/ english/undang2_en.

Malcolm X and Haley, A. 1987. The autobiography of Malcolm X. Available at: http://www.goodreads.com/author/ quotes/17435.Malcolm_X

McClaskey, H. C. 1977. Training and research in correctional librarianship. Library Trends, 26(1), 39-52.

McGiffin, P. A. 1990. The school media specialist as resource person: A descriptive study. University of Massachusetts, pp.260.

Omagbemi, C.O. and Odunewu, A.O. 2008. An appraisal of library services provision to prison inmates in Nigeria. Information, Society and Justice, Vol. 1, no. 2: 245

Pendleton, V. E.M and Chatman, E. A. 1998. Small world lives : Implications for the public library. Library Trends, Vol. 46, no. 4: 732-751.

Pickard, A. 2004. Young people and the Internet. Library and Information Update, Vol. 3, no. 1: 32-34.

Prison Department of Malaysia. 2000. Malaysia prison regulations. Available at: http://www.prison.gov.my/portal/page/portal/english/undang2_en.

Prison Department of Malaysia. 2013. Jumlah juvana sabitan dan reman yang ditempatkan di setiap penjara di Malaysia sehingga 20 April 2013 (Berumur 21 tahun ke bawah). Unpublished statistics. Jabatan Penjara Malaysia : Kajang.

Rafedzi, E.R.K and Abrizah, A. 2016. Information needs of male juvenile delinquents: The needs to be met in a prison setting. Information Development, Vol. 32, no. 3: 592-607, doi:10.1177/0266666914563357.

Rubin, J. R. and Suvak, D. S. 1995. Services. Libraries Inside : A practical guide for prison librarians. North Carolina: McFarland.

Shirley, G. L. 2003. Correctional libraries, library standards and diversity. Journal of Correctional Education, Vol. 54, no. 2. Available at: http://findarticles.com /p/articles/mi_qa4111/is_200306/ai_n9296955.

Šimunić, Z. Tanacković, S.F. and Badurina, B. 2016. Library services for incarcerated persons: A survey of recent trends and challenges in prison libraries in Croatia. Journal of Librarianship and Information Science, Vol. 48, no. 172-89. doi:10.1177/ 0961000614538481.

Stearns, R. M. 2004. The prison library : An issue for corrections, or a correct solution for its issues? Behavioral and Social Sciences Librarian, Vol. 23, no. 1: 49. 
Stevens, T. and Usherwood, B. 1995. The development of the prison library and its role within the models of rehabilitation. The Howard Journal of Criminal Justice, Vol. 34, no. 1: 45.

Sullivan, L. E. 2008. Prison is dull today: Prison libraries and the irony of pious reading. PMLA, Vol. 123, no. 3: 703-706. Available at: http://www.jstor.org/stable/25501891 31 July 2014.

Tarzaan, P. M., Chorun, M. T. and Mbatsoron, V. M. 2015. Information needs and seeking behaviour of prisoners' at the Medium Security Prison in Makurdi Local Government Area of Benue State. International Journal of Academic Library and Information Science. Vol. 3, no. 7: 193-209.

Wilhelmus, D. W. 1998. The influence of Casey V. Lewis on academic collections located in Indiana Prison Libraries. Indiana Libraries, Vol. 17, no. 2: 13-20.

Zeman, M. 2014. Tales of a jailhouse librarian: Challenging the juvenile justice system one book at a time. Vinegar Hill Press. 